\title{
THE
}

\section{Bacterial Community Profiling of the Eastern Oyster (Crassostrea virginica): Comparison of Culture-Dependent and Culture- Independent Outcomes}

\author{
Kenneth J. La Valley \\ Steve Jones \\ Marta Gomez-Chiarri \\ University of Rhode Island, gomezchi@uri.edu \\ Joseph DeAlteris \\ University of Rhode Island, jdealteris@uri.edu \\ Michael A. Rice \\ University of Rhode Island, mrice@uri.edu
}

Follow this and additional works at: https://digitalcommons.uri.edu/favs_facpubs

Terms of Use

All rights reserved under copyright.

\section{Citation/Publisher Attribution}

LaValley, K. J., Jones, S., Gomez-Chiarri, M., DeAlteris, J., \& Rice, M. (2009). Bacterial Community Profiling of the Eastern Oyster (Crassostorea virginica): Comparison of Culture-Dependent and CultureIndependent Outcomes. Journal of Shellfish Research, 28(4), 827-835. doi: 10.2983/035.028.0412 Available at: http://dx.doi.org/10.2983/035.028.0412

This Article is brought to you for free and open access by the Fisheries, Animal and Veterinary Sciences at DigitalCommons@URI. It has been accepted for inclusion in Fisheries, Animal and Veterinary Sciences Faculty Publications by an authorized administrator of DigitalCommons@URI. For more information, please contact digitalcommons-group@uri.edu. 


\section{Bacterial Community Profiling of the Eastern Oyster (Crassostrea virginica): Comparison of Culture-Dependent and Culture-Independent Outcomes}

Author(s): Kenneth J. La Valley, Steve Jones, Marta Gomez-Chiarri, Joseph Dealteris and Michael Rice Source: Journal of Shellfish Research, 28(4):827-835. 2009.

Published By: National Shellfisheries Association

DOI: http://dx.doi.org/10.2983/035.028.0412

URL: http://www.bioone.org/doi/full/10.2983/035.028.0412

BioOne (www.bioone.org) is a nonprofit, online aggregation of core research in the biological, ecological, and environmental sciences. BioOne provides a sustainable online platform for over 170 journals and books published by nonprofit societies, associations, museums, institutions, and presses.

Your use of this PDF, the BioOne Web site, and all posted and associated content indicates your acceptance of BioOne's Terms of Use, available at www.bioone.org/page/terms_of_use.

Usage of BioOne content is strictly limited to personal, educational, and non-commercial use. Commercial inquiries or rights and permissions requests should be directed to the individual publisher as copyright holder. 


\title{
BACTERIAL COMMUNITY PROFILING OF THE EASTERN OYSTER (CRASSOSTREA VIRGINICA): COMPARISON OF CULTURE-DEPENDENT AND CULTURE-INDEPENDENT OUTCOMES
}

\author{
KENNETH J. LA VALLEY, ${ }^{1 *}$ STEVE JONES, ${ }^{1}$ MARTA GOMEZ-CHIARRI, ${ }^{2}$ \\ JOSEPH DEALTERIS ${ }^{2}$ AND MICHAEL RICE ${ }^{2}$ \\ ${ }^{1}$ University of New Hampshire, 131 Main Street, Durham, NH 03824; ${ }^{2}$ University of Rhode Island, Lower \\ College Road, Kingston, RI 02881
}

\begin{abstract}
Tissue-associated bacterial community profiles generated using a nested polymerase chain reaction-denaturing gradient gel electrophoresis (DGGE) approach and culture-dependent and culture-independent isolation techniques were compared. Oyster samples were collected from 2 harvest areas along the coast of Maine, in the United States. Profiles from both isolation strategies were evaluated using Sorensen's index of similarity and cluster analysis of gel banding patterns. Cultureindependent profiles were further evaluated using the Shannon diversity index. In general, the culture-dependent strategy resulted in a greater number of bands within a profile. Bacterial DGGE profiles were found to be highly similar within an isolation strategy, with a higher degree of unrelatedness between culture-dependent and -independent techniques. Cluster analysis identified bands present in the culture-dependent strategy and not the total DNA technique, and vice versa. Significant differences in community profiles between oyster-associated and seawater were observed, indicating a diverse group of specialist bacterial species inhabit and are able to proliferate within the oyster.
\end{abstract}

KEY WORDS: bacteria, denaturing gradient gel electrophoresis, culture-dependent, culture-independent, community profiling, oyster, Crassostrea virginica

\section{INTRODUCTION}

The bacterial communities within the Eastern Oyster (Crassostrea virginica) have been characterized mainly from a public health standpoint. Being filter feeders, oysters may accumulate human pathogens to levels considerably greater than those in the overlying water (Metcalf et al. 1979, Rippey et al. 1994, Burkhardt \& Calci 2000). Because the majority of oysters are sold for the half-shell raw market, pathogens of interest have focused on fecal contamination, enteric pathogens and viruses from harvest areas, as well as Vibrio parahaemolyticus and $V$. vulnificus strains (Pujalte et al. 1999, Burkhardt \& Calci 2000). In addition, studies on the natural bacterial fauna of oysters have been carried out (Olafsen et al. 1993, Brady et al. 1998, Pujalte et al. 1999); however, these studies have focused on the seasonal bacterial content of bivalves, or on selected genera. Understanding the dynamics of microbial communities of the oyster will provide insight into water pollution sources and estuarine health, and may assist with the development of new purification strategies for shellfish-borne human pathogens.

The development of molecular techniques based on polymerase chain reaction (PCR) have enabled researchers to circumvent the limitations associated with culture-dependent methods (i.e., general low culturability and a bias for species suited to specific growth media, enrichments, and temperatures) (Cottrell \& Kirchman 2000, Nocker et al. 2004). It is estimated that less than $1 \%$ of bacteria in nature are culturable using currently available methods (Amann et al. 1995, Cottrell \& Kirchman 2000, Nocker et al. 2004). PCR-based methods have produced a surge in bacterial community research from both marine and terrestrial organisms and environments (Duarte et al. 1998, Gelsomino et al. 1999, Simpson et al. 1999, Fandino et al. 2001, Seibold et al. 2001, Kawai et al. 2002, Wakefield \&

\footnotetext{
*Corresponding author. E-mail: ken.lavalley@unh.edu.
}

Gaffney 2002). In fact, molecular techniques now supplement and in some cases replace classic culture-dependent techniques (Friedrich et al. 2000, Simpson et al. 2000, Boon et al. 2002). Denaturing gradient gel electrophoresis (DGGE), one such method, provides a technique that allows relatively small DNA fragments to be separated by single base pair differences (Miller et al. 1999). This technique was originally used to detect point mutations in DNA sequences (Cariello et al. 1991, Abrams \& Stanton 1992, Keohavong et al. 1993, Norman et al. 1994), but its use was soon expanded to include quantifying the diversity of microbial populations (Muyzer et al. 1993, Brinkhoff \& Muyzer 1997, Ovreas et al. 1997). Early distribution and abundance studies used DGGE to analyze the sequence diversity of natural microbial populations. This was accomplished by developing PCR primers that would target specific variable domains of the $16 \mathrm{~S}$ ribosomal DNA (rDNA) fragments for a particular microbial group or species. For example, specific primers were developed for the identification of ammonia oxidizers (Kowalchuk et al. 1997), methane oxidizers (Henckel et al. 1999), sulfur oxidizing Thiomicrospira spp. (Brinkhoff \& Muyzer 1997), and Desulfovibrio spp. using PCR primers specific to $[\mathrm{NiFe}]$ hydrogenase gene sequences (Wawer \& Muyzer 1995), as well as for marine benthic Archaea in deepsea sediments (Vetriani et al. 1999).

To our knowledge total bacterial community profiles of the Eastern Oyster have not been quantified using culture-independent DGGE methods, nor has a comparison of isolation techniques been considered. The objective of this study is to evaluate diversity and abundance of oyster-associated bacteria using both culture-dependent and culture-independent isolation techniques. DGGE will be used to visualize dominant ribotypes as banding profiles. During DGGE analysis of populations, the number and precise position of the bands in a gel lane give an estimate of the number or relative abundance of dominant ribotypes in a sample (Cottrell \& Kirchman 2000). In general, 
DGGE studies assess the diversity of microbial organisms on the basis of the number and patterns of bands alone. However, PCR-based techniques do allow semiquantification based on the intensity of the band (McCartney 2002, Kirk et al. 2004). Studies have used band intensity to characterize bacterial diversity in soils (Dilly et al. 2004), from wastewater treatment plants (Boon et al. 2002), for grassland bacterial community structure (McCaig et al. 2001), peat-forest soil (Ramirez-Saad et al. 2003), and coastal oligotrophic systems (Schauer et al. 2003). For this study we will use band intensity as a relative indication of diversity for the culture-independent profiles. Estimates of abundance based on band intensity must be relative in nature and carefully interpreted to recognize the potential for multiple bands from a single species. This analysis will begin to describe the bacterial community of the oyster and how these communities are affected by site of harvest and season.

\section{MATERIALS AND METHODS}

\section{Sample Collection}

Eastern Oyster (Crassostrea virginica) samples were collected from Spinney Creek Shellfish, Inc., a shellfish depuration facility in Eliot, ME. Oysters originated from 2 harvest areas that represented different environmental conditions. The sources were as follows: (1) Spinney Creek, ME, a man-made embayment characterized by a mid temperature range and stable high salinity, and (2) Bay Falls, ME, the northern most source, characterized by cold temperature and fluctuating tidal mid salinity.

Upon arrival, samples were immediately processed to minimize changes in bacterial communities that may have occurred during transport to the shellfish processing facility. These samples represented the environmental bacterial population present from each locations harvest area. Samples were processed as either individual oysters or composites. Composite samples consisted of a blend of 12 individual oyster meats and liquor, or approximately $200 \mathrm{~g}$. This is considered a sufficient sample to reflect the harvested population, and reflects procedures outlined in the U.S. Food and Drug Administration Biological Analytical Manual (1998).

To compare the effect of culture-dependent bacterial isolation techniques to direct DNA extraction, samples were processed following 2 procedures. For each sample, tissue and liquor were aseptically removed, homogenized, and either immediately processed for DNA extraction or cultured in Marine 2216 enrichment broth (Zobell 1941). In this way, relative species abundance could be estimated from both total DNA (tissue) and cultured DNA (colonies) sources. Marine broth enrichments were incubated overnight at room temperature and 5-mL aliquots were aseptically removed from borosilicate glass incubation tubes for DNA extraction. The bacterial community profile comparisons are described by harvest area and bacterial genomic DNA source in Table 1.

To relate the environmental source water to oysterassociated bacterial profiles, triplicate $2-\mathrm{L}$ water samples were harvested from the water column at the same position and time that oyster samples were harvested. Water samples were filtered through $0.45-\mu \mathrm{m}$ membrane filtration paper transferred to Marine 2216 broth and incubated overnight at room temperature. DNA was prepared from the water sample and compared with the Bay Falls environmental samples.
TABLE 1.

Summary of DGGE comparisons made by sample source and harvest area.

\begin{tabular}{|c|c|c|c|c|c|}
\hline \multirow[b]{3}{*}{ Harvest Area } & \multicolumn{5}{|c|}{ DNA Source } \\
\hline & \multicolumn{3}{|c|}{$\begin{array}{c}\text { Bacteria Cultured } \\
\text { with Marine } \\
2216 \text { Agar }\end{array}$} & \multicolumn{2}{|c|}{$\begin{array}{c}\text { Culture } \\
\text { Independent }\end{array}$} \\
\hline & $\begin{array}{c}\text { Individual } \\
\text { Oyster } \\
\text { Sample }\end{array}$ & $\begin{array}{l}\text { Pooled } \\
\text { Oyster } \\
\text { Sample }\end{array}$ & $\begin{array}{l}\text { Harvest } \\
\text { Area } \\
\text { Seawater } \\
\text { Sample }\end{array}$ & $\begin{array}{c}\text { Individual } \\
\text { Oyster } \\
\text { Sample }\end{array}$ & $\begin{array}{r}\text { Pooled } \\
\text { Oyster } \\
\text { Sample }\end{array}$ \\
\hline Spinney Creek, ME & $\mathrm{X}$ & & & $\begin{array}{l}X \\
X\end{array}$ & $\mathrm{X}$ \\
\hline Bay Falls, ME & $\begin{array}{l}X \\
X \\
X\end{array}$ & $\mathrm{X}$ & $\mathrm{X}$ & $\begin{array}{l}X \\
X\end{array}$ & \\
\hline
\end{tabular}

\section{Genomic DNA Extraction from Oysters and Bacterial Cultures}

The Gentra Puregene DNA Purification Kit (Gentra Systems, Minneapolis, MN) was used for all DNA extractions. Oyster samples were homogenized using a stomacher bag. Five milligrams of the blended tissue was added to cell lyses and proteinase $\mathrm{K}$ solutions $(20 \mathrm{mg} / \mathrm{mL})$. Total DNA was extracted using the Puregene ${ }^{\mathrm{TM}}$ system following the manufacturer's instructions, and the samples were stored at $4^{\circ} \mathrm{C}$.

The Puregene Gram-negative bacteria protocol was used to prepare and extract DNA from overnight Marine 2216 broth enrichments. Five milliliters of the overnight cell suspension was added to a $15-\mathrm{mL}$ centrifuge tube and was centrifuged at $1,000 \mathrm{~g}$ for $3 \mathrm{~min}$ to pellet cells. The remaining liquid was decanted from the centrifuge tube, leaving the bacterial pellet. Cell lyses and proteinase $\mathrm{K}$ solutions $(20 \mathrm{mg} / \mathrm{mL})$ were added to the sample and incubated in a shaking waterbath at $37^{\circ} \mathrm{C}$ for $5 \mathrm{~h}$ or until the pellet had completely dissolved into solution. After cell lysis, genomic DNA was extracted per manufacturer's recommendations.

\section{Polymerase Chain Reaction and Denaturing Gradient Gel Electrophoresis}

Nested PCR was used to amplify approximately $200 \mathrm{bp}$ of the third hypervariable region (V3) of the bacterial 16S rRNA (Rohwer et al. 2001). PCR reactions were assembled, including $1 \mu \mathrm{M}$ of the 27F (5'-AGAGTTTGATCMTGGCTCAG-3') bacterial-specific primer, $1 \mu \mathrm{M}$ of the $1,492 \mathrm{R}$ ( $5^{\prime}$-TACGGCTA CCTTGT-3') universal primer, 1 U REDTaq (Sigma-Aldrich, St. Louis, MO), $1 \times$ PCR buffer, $10 \mathrm{mM}$ each deoxynucleotide triphosphate (dNTP), approximately $1-\mu \mathrm{g}$ sample DNA, incubated for $5 \mathrm{~min}$ at $94^{\circ} \mathrm{C}$, and then for 15 cycles of $1 \mathrm{~min}$ at $94^{\circ} \mathrm{C}$, $1 \mathrm{~min}$ at $62^{\circ} \mathrm{C}, 3 \mathrm{~min}$ at $72^{\circ} \mathrm{C}$, with a final extension of $10 \mathrm{~min}$ at $72^{\circ} \mathrm{C}$ (Rohwer et al. 2001). Then, using methods by Muyzer et al. (1993) and Riemann et al. (1999), a 5- $\mu \mathrm{L}$ aliquot of this reaction was transferred to a second PCR tube with $1 \mu \mathrm{M}$ each of the bacterial-specific $341 \mathrm{~F}$ (5' CGCCCGCCGCGCGCGGCGGGCGGGGCGGGGGGCCGGGGGCCTACCGGAGGCAGC-3') primer with a 40-bp GC-clamp (underlined), $1 \mu \mathrm{M}$ of the 517R (5'-ATTACCGC GGCTGCTGG-3') primer, $1 \mathrm{U}$ REDTaq, $1 \times$ buffer, and $10 \mathrm{mM}$ each dNTP. This second 
reaction began with an initial denaturation at $94^{\circ} \mathrm{C}$ for 5 min followed by a thermal cycling program as follows: 1 min at $94^{\circ} \mathrm{C}$; 1 min at $65^{\circ} \mathrm{C}$, decreasing $1^{\circ} \mathrm{C}$ every 2 cycles to a final of $50^{\circ} \mathrm{C}$ (Don et al. 1991, Riemann et al. 1999); 3-min primer extension for $3 \mathrm{~min}$ at $72^{\circ} \mathrm{C}$. In total, 30 cycles were run with a final extension of $7 \mathrm{~min}$ at $72^{\circ} \mathrm{C}$ (Don et al. 1991).

After PCR, approximately 500 ng DNA of each sample was loaded onto a $30-70 \%$ denaturing gradient gel. Gels were run for $5.5 \mathrm{~h}$ at $200 \mathrm{~V}$ and $60^{\circ} \mathrm{C}$ (Riemann et al. 1999). After electrophoresis, gels were stained with $15 \mu \mathrm{L}$ ethidium bromide in 250 $\mathrm{mL} 1 \times$ Tris acetate EDTA for $30 \mathrm{~min}$, then destained for $10 \mathrm{~min}$ in $1 \times$ TAE. Gel patterns were photographed with ultraviolet transillumination (Riemann et al. 1999).

\section{Analysis of DGGE Patterns and Statistical Analysis}

The processing of the DGGE gels was done using the UVP Laboratory Imaging and Analysis System (UVP Doc-It v4.0, UVP, Upland, CA) software package. For this evaluation, we considered DGGE gel banding profiles to be representative of only the dominant ribotypes from within a sample and not a complete picture of bacterial diversity. To address the selectivity biases associated with enrichment broth cultures compared with total DNA extractions, comparisons between culture-independent and culture-dependent profiles were made using Sorensen's index of similarity (Nakatsu et al. 2000). Sorensen's similarity coefficient determines relatedness of DGGE profiles based on the presence or absence of each band between 2 lanes. Two bands were considered common if they migrated the same distance on the gel.

Cluster analysis was performed on each gel with StatistiXL v1.5 (Kalamunda, Western Australia). Cluster analysis was performed using squared Euclidian distances of peak optical band densities and Ward's algorithm. The clustering algorithm of Ward (1963), was used to calculate the dendrograms of each DGGE gel. Cluster diagrams were not used to compare culturedependent and independent profiles, but were used to identify common and absent bands from within each strategy.

The structural diversity of the microbial community was examined for culture-independent profiles using the Shannon index of general diversity $H$ (Shannon 1948). $H$ was calculated on the basis of the bands on the gel tracks and their corresponding relative abundance indicated by band intensity (Boon et al. 2002). The greater the $H$ index, the greater the relative diversity of the bacterial community.

The distribution of the relative number of individuals among different species was calculated by the Shannon equitability index. This estimate of evenness assumes a value between 0 and 1 , with 1 being complete evenness or all relative species densities equal for a population (Boon et al. 2002).

Statistical differences between relative diversity coefficients for composite and individual culture-independent samples were identified by analysis of variance (StatistiXL v1.5, StatistiXL, Kalamunda, Western Australia). Specific differences were identified using Tukey's post hoc test.

\section{RESULTS}

The bacterial community profiles of the Eastern Oyster were investigated through DGGE analysis of oysters harvested from Bay Falls, ME, and Spinney Creek, ME, harvest areas. They were compared for differences in community profiles and diversity indices using both culture-dependent and -indepen- dent methods. With the first approach, bacterial DNA was extracted from oyster tissue/liquor samples after an enrichment step; the second approach involved bacterial DNA extraction directly from oyster tissue/liquor samples. All harvest areas were qualitatively compared for differences in DGGE banding patterns and the numbers of dominant ribotypes detected. In addition, the temporal effect on DGGE banding patterns was compared for the Spinney Creek harvest area.

\section{Similarity Comparison of Culture-Dependent and Culture-Independent DGGE Profiles}

DGGE gel patterns were determined for the DNA source comparisons of the Spinney Creek and Bay Falls harvest areas. Several dominant bacterial ribotypes, represented as dark bands, could be identified in each treatment (Figs. 1 and 2). In addition to the dominant bands, most samples produced higher numbers of weak bands. These weaker bands were assumed to represent the less dominant ribotypes. For the Spinney Creek sample, there was little variation in banding patterns between oysters for each community profiling technique (Fig. 1). DGGE profiles were more similar within than between the 2 isolation techniques. Although different banding patterns were apparent, the same general results were observed for the Bay Falls sample analysis (Fig. 2).

Based on the presence and absence of bands in each sample, similarity coefficients were determined for the DGGE profiles generated using culture-dependent and -independent community profiling techniques. For oysters harvested from Spinney Creek, Sorensen's similarity coefficient $\left(\mathrm{C}_{\mathrm{s}}\right)$ ranged from 0.75 0.94 within culture-dependent profiles and $0.92-1.0$ for cultureindependent profiles (Table 2). Similarity was low between DNA isolation strategies for Spinney Creek $\left(C_{s}=0.26-0.50\right)$. Comparable results were observed for Bay Falls, which showed low similarity between isolation strategies $\left(\mathrm{C}_{\mathrm{s}}=0.14-0.60\right)$. The two profiling methods provide different, but complementary, pictures of the bacterial community in the sampled oysters. In general, more DGGE bands were observed from samples that were cultured in Marine 2216 broth, suggesting amplification of ribotypes from low-density populations in culture. The cultureindependent samples were observed to have fewer bands overall and generally lower optical densities from the densitometric curves. The DGGE profiles indicate that oysters are populated by several dominant ribotypes that colonize and share the tissue surfaces with a greater number of low-density ribotypes. Because the liquor was not excluded when processing the tissue samples, it was not possible to determine which ribotypes represented surface-attached bacteria and which resided within the liquor itself.

\section{Temporal Variation in Individual and Pooled Oysters}

Temporal effects were studied for the Spinney Creek bacterial community profiles. An increase in the number of bands or dominant ribotypes was observed over the 2 sampling times using both culture-dependent and -independent isolation techniques in the DGGE gel patterns. This change was observed for culturedependent samples as a low similarity between profiles for oysters collected on the 2 sampling dates $\left(60 \%\right.$ of $\left.\mathrm{C}_{\mathrm{s}}<0.50\right)$. The 2 -wk period between samples coincided with an increase in water temperature from $9-15^{\circ} \mathrm{C}$. In general, culture-dependent composite and individual DGGE banding profiles were similar $\left(\mathrm{C}_{\mathrm{s}}>0.50\right)$. 


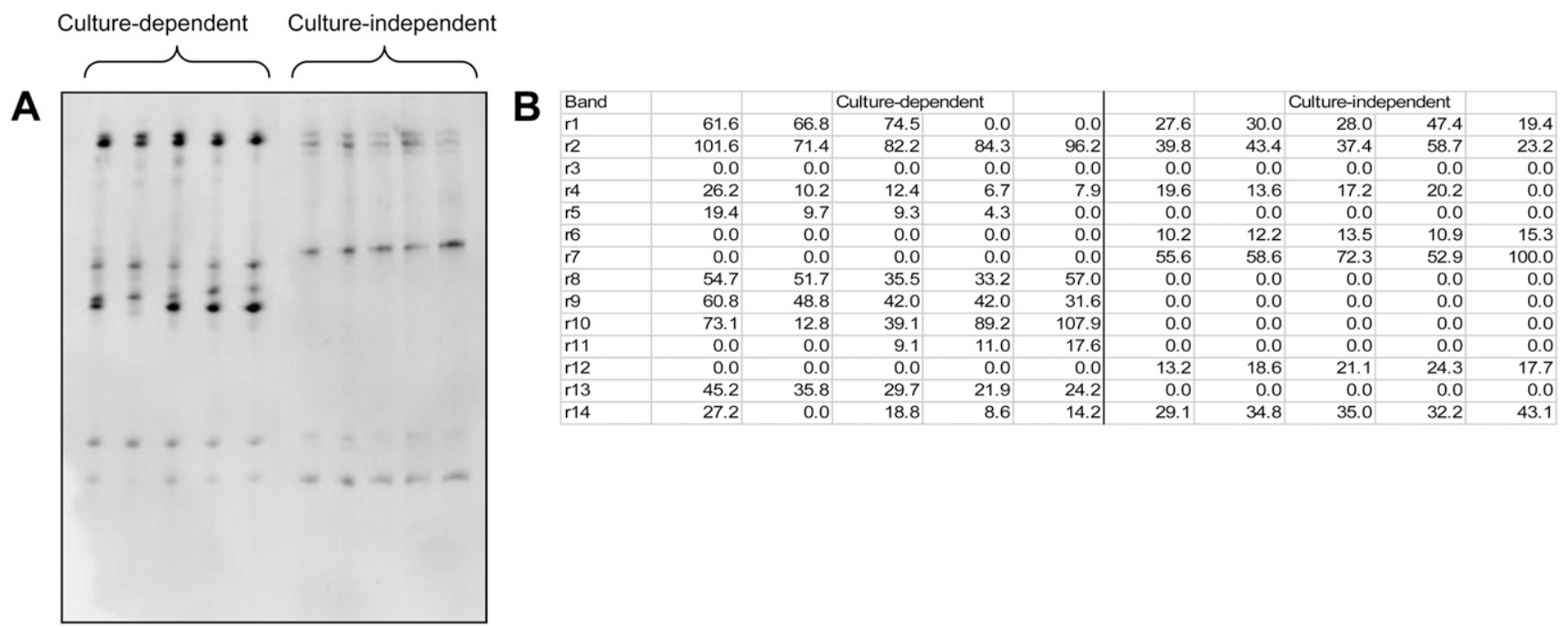

Figure 1. DGGE bacterial community profiles of Spinney Creek, ME, oysters using culture-dependent and -independent techniques (a), and corresponding intensity of density peaks with band indicators.

For the culture-independent comparisons, the densitometric curve of the gel track was used to estimate the number and relative abundance of dominant bacterial ribotypes (Riemann et al. 1999, McCaig et al. 2001, Rohwer et al. 2001, Boon et al. 2002, Ramirez-Saad et al. 2003). The results of calculating average diversity indices showed the individual May 13 patterns to have the greatest diversity $(H)$, variation of numbers of individual patterns (E), and abundance of species (S) compared with the other 2 pattern sets (Table 3). Significant differences in the number of bands $(S)$ or relative diversity of bands $(H)$ between experimental groups were observed $(P<0.0001$, Table 4$)$. Using normalized band intensity to estimate relative diversity $(H)$, a significant difference in mean relative intensity of the bands was also detected $(P<0.0001$, Table 4$)$. The observed changes in relative abundance and diversity coincided with the increase in water temperature during the 2-wk sample interval. Tukey's post hoc test demonstrated significant increases in relative abundance and diversity between individual oyster sample profiles taken from April 27th and May 13th samples (Table 4).

\section{Effect of Seawater Source on Oyster-Associated Ribotypes Using Culture-Dependent Methods}

More than $86 \%$ of bands were shared between the seawater and corresponding oyster-associated bacterial community DGGE profiles. Similarity was low $\left(\mathrm{C}_{\mathrm{s}}=0.19-0.50\right)$, however, between source water and oyster profiles, because the oyster profiles produced a greater number of bands than the source water samples (Table 5). Relatedness was higher within seawater profiles $\left(\mathrm{C}_{\mathrm{s}}=0.82-0.95\right)$ and oyster-associated bacterial profiles $\left(\mathrm{C}_{\mathrm{s}}=0.35-0.85\right)$ than between water and oyster profiles.

\section{Cluster Analysis of Oyster Bacterial Community Profiles}

Dendrograms for cluster analyses were generated for both harvest areas. We expected aggregations of bands to be generated that would divide bands into several dominant ribotypes and those remaining, low-abundance fragments. The cluster analysis groups DGGE bands together by intensity; therefore, dominant high-intensity bands, midintensity, and low-intensity bands would be grouped together to form a hierarchical cluster. This grouping would minimize the within cluster variation while maximizing differences between clusters. Because we observed differences in similarity between the culture-dependent and -independent techniques, we expected the cluster analysis to create groups that represented ribotypes that were either not observed in 1 technique or increased or decreased in abundance between the 2 isolation methods. In both harvest areas, bands were observed in the culture-dependent technique that were not visualized in the independent profiles, and vice versa. For example, a cluster of 6 bands ( $\mathrm{r} 3, \mathrm{r} 5, \mathrm{r} 8, \mathrm{r} 9, \mathrm{r} 10$, and r13) observed in the cultureindependent analysis was not detected in the culture-dependent analysis of Spinney Creek oysters (Fig. 3). Also, low-density (r6 and r12) and high-density (r12) ribotypes observed in the culture-independent profiles did not appear in the cultured profiles (Fig. 3). Similar observations were made for the Bay Falls harvest area (Fig. 4). The relative abundance of dominant ribotypes increased for the cultured profiles. Again, several high-abundance bands (r5, r13, and r14) were visualized after culturing (Fig. 4). In addition, high- (r12) and low- (r17) abundance ribotypes from the tissue extractions did not appear in the cultured profiles (Fig. 4).

\section{DISCUSSION}

The major findings were as follows: (1) Isolation techniques provide different, but complementary pictures of the bacterial community of the oyster; (2) bacterial community from oysters from a particular site and time are very similar; (3) bacterial community in the oyster is influenced by season and site; and (4) bacterial communities of the oyster are different than the community in seawater.

It is generally accepted that the majority of microbes are not easily cultured using standard microbiological techniques, and that culture-independent techniques would provide a more complete picture of bacterial communities (Friedrich et al. 


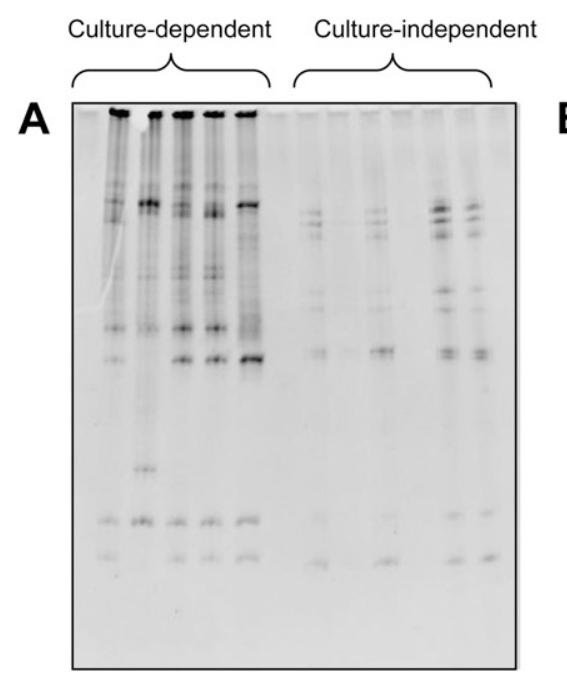

\begin{tabular}{|c|c|c|c|c|c|c|c|c|c|c|}
\hline \multirow{2}{*}{$\begin{array}{l}\text { Bands } \\
\mathrm{r} 1\end{array}$} & \multirow[b]{2}{*}{36.2} & \multicolumn{3}{|c|}{ Culture-dependent } & \multirow[b]{2}{*}{31.1} & \multirow[b]{2}{*}{0.0} & \multicolumn{3}{|c|}{ Culture-independent } & \multirow[b]{2}{*}{33.4} \\
\hline & & 36.3 & 57.2 & 44.3 & & & 0.0 & 0.0 & 73.2 & \\
\hline 12 & 55.1 & 132.1 & 67.3 & 59.2 & 137.4 & 23.3 & 0.0 & 21.9 & 59.2 & 28.4 \\
\hline r3 & 0.0 & 42.5 & 60.6 & 91.6 & 31.3 & 30.5 & 12.0 & 26.8 & 42.9 & 21.3 \\
\hline r4 & 47.6 & 0.0 & 0.0 & 0.0 & 40.0 & 18.9 & 0.0 & 23.9 & 0.0 & 0.0 \\
\hline r5 & 0.0 & 21.1 & 33.8 & 33.6 & 35.2 & 0.0 & 0.0 & 0.0 & 0.0 & 0.0 \\
\hline r6 & 24.0 & 21.7 & 42.3 & 50.0 & 28.2 & 0.0 & 0.0 & 0.0 & 36.1 & 14.5 \\
\hline r7 & 22.9 & 27.5 & 43.6 & 56.1 & 29.1 & 13.9 & 0.0 & 14.9 & 0.0 & 0.0 \\
\hline r8 & 16.9 & 0.0 & 32.1 & 36.5 & 0.0 & 0.0 & 11.0 & 17.9 & 27.4 & 12.6 \\
\hline r9 & 0.0 & 20.1 & 32.1 & 30.6 & 35.7 & 17.0 & 0.0 & 0.0 & 0.0 & 0.0 \\
\hline $\mathrm{r} 10$ & 21.3 & 0.0 & 0.0 & 0.0 & 0.0 & 0.0 & 0.0 & 0.0 & 0.0 & 0.0 \\
\hline r11 & 43.1 & 37.5 & 83.3 & 83.5 & 52.1 & 0.0 & 0.0 & 0.0 & 42.9 & 38.1 \\
\hline $\mathrm{r} 12$ & 0.0 & 0.0 & 0.0 & 0.0 & 0.0 & 21.7 & 11.6 & 51.8 & 36.9 & 35.4 \\
\hline $\mathrm{r} 13$ & 23.9 & 0.0 & 66.1 & 74.4 & 127.5 & 0.0 & 0.0 & 0.0 & 0.0 & 0.0 \\
\hline $\mathrm{r} 14$ & 0.0 & 31.4 & 0.0 & 0.0 & 0.0 & 0.0 & 0.0 & 0.0 & 0.0 & 0.0 \\
\hline r15 & 0.0 & 0.0 & 0.0 & 0.0 & 0.0 & 0.0 & 0.0 & 10.2 & 15.3 & 11.9 \\
\hline r16 & 19.3 & 38.5 & 26.7 & 29.9 & 32.7 & 9.1 & 0.0 & 0.0 & 0.0 & 0.0 \\
\hline r17 & 0.0 & 0.0 & 0.0 & 0.0 & 0.0 & 0.0 & 0.0 & 21.9 & 17.8 & 21.0 \\
\hline r18 & 10.8 & 0.0 & 11.9 & 12.9 & 19.4 & 14.9 & 5.7 & 0.0 & 0.0 & 0.0 \\
\hline
\end{tabular}

Figure 2. DGGE bacterial community profiles of Bay Falls, M.E. oysters using culture-dependent and -independent techniques (a); and corresponding intensity of density peaks with band indicators.

2000). The culture environment will preferentially bias the growth and abundance of micro-organisms best suited to the nutrient, temperature, and time given for incubation. As such, one would expect only a few species to dominate the culture, thereby producing a community profile of the organisms that were able to use the culture medium best (Don et al. 1991, Furhman \& Campbell 1998). We expected to see a substantial difference in the numbers of species detected and relative abundance between the culture-dependent and independent isolation techniques. The cultured samples were expected to produce lower diverse communities characterized by few highabundance species. As expected, the 2 isolation strategies resulted in different banding profiles. In general, Sorensen's similarity coefficient was low between culture-dependent and culture-independent approaches, indicating unrelatedness between the 2 approaches. Cluster analysis identified several bands present in culture-dependent profiles that were not observed in total DNA extractions, and vice versa. These results indicate that several micro-organisms present in low numbers in the oyster, below the detection limit using the total DNA method, were able to use the enrichment broth and increase to a detectable density. Several studies have documented similar effects of the isolation method on the estimates of microbial populations using DGGE (Santegoeds et al. 1996, Head et al. 1998, Bernard et al. 2000, Ercolini et al. 2001, Smit et al. 2001, Miambi et al. 2003, Temmerman et al. 2003, Rantsiou et al. 2005). Several lactic acid bacteria were revealed from culture that was not observed from direct DNA extractions of buffalo cheese samples (Ercolini et al. 2001). Bernard et al. (2000) used a variety of techniques to access the total, active, and culturable marine bacteria in coastal seawater samples. When comparing culturable results with those obtained from total DNA samples, they concluded that an important source of genetic diversity may be missed if direct DNA extractions were solely considered. By combining culture-dependent and -independent methodologies, a more complete picture of the diversity of marine bacterial communities can be predicted (Ellis et al. 2003, Kisand \& Wikner 2003).

The previously observed increase in the diversity of microorganisms detected by analysis of samples using culture-independent

TABLE 2.

Sorensen's similarity coefficient of DGGE profiles of the bacterial community associated with oysters from Spinney Creek and isolated using culture-dependent (lanes 1-5) and culture-independent (lanes 6-10) methods.

\begin{tabular}{|c|c|c|c|c|c|c|c|c|c|c|c|}
\hline \multirow[b]{2}{*}{ Culture Type } & \multirow[b]{2}{*}{ Lanes Compared } & \multicolumn{5}{|c|}{ Culture Dependent } & \multicolumn{5}{|c|}{ Culture Independent } \\
\hline & & 1 & 2 & 3 & 4 & 5 & 6 & 7 & 8 & 9 & 10 \\
\hline \multirow{5}{*}{ Culture dependent } & 1 & 1.00 & & & & & & & & & \\
\hline & 2 & 0.94 & 1.00 & & & & & & & & \\
\hline & 3 & 0.84 & 0.88 & 1.00 & & & & & & & \\
\hline & 4 & 0.88 & 0.82 & 0.95 & 1.00 & & & & & & \\
\hline & 5 & 0.82 & 0.75 & 0.88 & 0.94 & 1.00 & & & & & \\
\hline \multirow{5}{*}{ Culture independent } & 6 & 0.50 & 0.40 & 0.47 & 0.37 & 0.40 & 1.00 & & & & \\
\hline & 7 & 0.50 & 0.40 & 0.47 & 0.37 & 0.40 & 1.00 & 1.00 & & & \\
\hline & 8 & 0.50 & 0.40 & 0.47 & 0.37 & 0.40 & 1.00 & 1.00 & 1.00 & & \\
\hline & 9 & 0.50 & 0.40 & 0.47 & 0.37 & 0.40 & 1.00 & 1.00 & 1.00 & 1.00 & \\
\hline & 10 & 0.40 & 0.28 & 0.42 & 0.26 & 0.28 & 0.92 & 0.92 & 0.92 & 0.92 & 1.00 \\
\hline
\end{tabular}


TABLE 3.

Mean and summary statistics of relative species diversity $(H)$, evenness $(E)$, and abundance $(S)$ estimates from analysis of the DGGE banding profiles of individual and composite oyster samples from Spinney Creek isolated using culture-independent profiles (Figs. 1-2).

\begin{tabular}{|c|c|c|c|c|c|}
\hline Index & Group & Mean & Standard Deviation & Standard Error & $n$ \\
\hline \multirow{3}{*}{ Species diversity index $(H)$} & Composite April 27 & 1.70 & 0.11 & 0.05 & 5.00 \\
\hline & Individual May 13 & 2.38 & 0.15 & 0.06 & 5.00 \\
\hline & Individual April 27 & 1.94 & 0.04 & 0.02 & 5.00 \\
\hline \multirow[t]{3}{*}{ Evenness index $(E)$} & Composite April 27 & 0.91 & 0.03 & 0.01 & 5.00 \\
\hline & Individual May 13 & 0.91 & 0.02 & 0.01 & 5.00 \\
\hline & Individual April 27 & 0.96 & 0.02 & 0.01 & 5.00 \\
\hline \multirow[t]{3}{*}{ Species abundance $(S)$} & Composite April 27 & 6.40 & 0.55 & 0.24 & 5.00 \\
\hline & Individual May 13 & 14.00 & 1.87 & 0.84 & 5.00 \\
\hline & Individual April 27 & 7.60 & 0.55 & 0.24 & 5.00 \\
\hline
\end{tabular}

techniques when compared with culture-dependent techniques (Don et al. 1991, Furhman \& Campbell 1998, Friedrich et al. 2000) was not observed in this analysis of the bacterial community of the oyster. On the contrary, a greater relative diversity of ribotypes was detected using culture-dependent isolation techniques in this study. Furthermore, about $50 \%$ of the bands were shared between the profiles obtained using the 2 isolation techniques. These results may be largely a product of method biases associated with the DNA extraction technique used, the PCR process, and the DGGE method itself. Over-

TABLE 4.

Analysis of variance and Tukey's post hoc test results of Shannon's diversity index comparisons made from Spinney Creek individual and composite culture-independent profiles (Figs. 1-2).

\begin{tabular}{llrcr}
\hline \hline \multicolumn{5}{c}{ Analyses of Variance } \\
\multicolumn{1}{c}{ Y Variable } & Source & df & F & $\boldsymbol{P}$ \\
\hline Species diversity & Model & 2 & 53.48 & 0.00 \\
index $(H)$ & & & & \\
& Error & 12 & & \\
Evenness index $(E)$ & Total & 14 & & \\
& Model & 2 & 8.50 & 0.01 \\
& Error & 12 & & \\
Species abundance $(S)$ & Total & 14 & & \\
& Model & 2 & 61.07 & 0.00 \\
& Error & 12 & &
\end{tabular}

Post Hoc Tests for Factor $=$ Sample Source

\begin{tabular}{cllc}
\hline \multicolumn{1}{c}{ Y Variable } & \multicolumn{1}{c}{ Group 1 } & \multicolumn{1}{c}{ Group 2 } & $\boldsymbol{P}$ \\
\hline $\begin{array}{l}\text { Species diversity } \\
\text { index }(H)\end{array}$ & Composite April 27 & Individual May 13 & 0.00 \\
& Composite April 27 & Individual April 27 & 0.01 \\
& Individual May 13 & Individual April 27 & 0.00 \\
Evenness & Composite April 27 & Individual May 13 & 0.79 \\
index $(E)$ & Composite April 27 & Individual April 27 & 0.02 \\
& Individual May 13 & Individual April 27 & 0.01 \\
Species & Composite April 27 & Individual May 13 & 0.00 \\
abundance $(S)$ & & & \\
& Composite April 27 & Individual April 27 & 0.27 \\
& Individual May 13 & Individual April 27 & 0.00 \\
\hline
\end{tabular}

amplification of specific rRNA fragments or those bacterial DNA fragments with the highest number of $16 \mathrm{~S}$ rDNA loci results in overrepresentation of the most abundant species in a sample and loss of underrepresented species (Rohwer et al. 2001, Rantsiou et al. 2005). The relative similarity in the diversity and composition of bacterial communities observed using culture-dependent and -independent techniques in this study may be the result of the unique environment of the external and internal surfaces of the oyster, which supply a nutrientrich microenvironment not unlike an enrichment broth. These microenvironments allow proliferation of the majority of bacterial species that specialize in these environments, thus inhibiting many of the transient bacterial species inadvertently ingested during respiratory and feeding mechanisms.

Temporal changes in DGGE profiles were observed regardless of isolation technique. The increase in bands over the sample interval coincided with temperatures exceeding $10^{\circ} \mathrm{C}$. Staroscik \& Smith (2004) documented a seasonal increase in bacterial abundance in Narragansett Bay, RI, which corresponded with the spring increase in seawater temperature above $10^{\circ} \mathrm{C}$. For our analysis, this increase in bands means that the relative abundance of those ribotypes increased over the time period, not necessarily that total bacterial abundance increased. The increase in bands may indicate either the presence of additional bacteria in the water column or that the oyster-associated

TABLE 5.

Sorensen's similarity coefficient of culture-dependent Bay Falls seawater profiles versus oyster profiles.

\begin{tabular}{|c|c|c|c|c|c|c|c|c|c|}
\hline \multirow[b]{2}{*}{ Source } & \multirow{2}{*}{$\begin{array}{c}\text { Lanes } \\
\text { Compared }\end{array}$} & \multicolumn{3}{|c|}{ Seawater } & \multicolumn{5}{|c|}{ Oyster } \\
\hline & & 1 & 2 & 3 & 4 & 5 & 6 & 7 & 8 \\
\hline \multirow{3}{*}{ Seawater } & 1 & 1.00 & & & & & & & \\
\hline & 2 & 0.95 & 1.00 & & & & & & \\
\hline & 3 & 0.82 & 0.87 & 1.00 & & & & & \\
\hline \multirow{5}{*}{ Oyster } & 4 & 0.20 & 0.19 & 0.27 & 1.00 & & & & \\
\hline & 5 & 0.43 & 0.50 & 0.40 & 0.61 & 1.00 & & & \\
\hline & 6 & 0.35 & 0.42 & 0.40 & 0.70 & 0.85 & 1.00 & & \\
\hline & 7 & 0.20 & 0.19 & 0.36 & 0.40 & 0.35 & 0.35 & 1.00 & \\
\hline & 8 & 0.35 & 0.42 & 0.48 & 0.44 & 0.54 & 0.62 & 0.70 & 1.00 \\
\hline
\end{tabular}

Lanes 1-3 are culture-dependent seawater profiles and lanes 4-8 are culture-dependent Bay Falls oyster-associated profiles. 
A Culture-independent Cluster Analysis
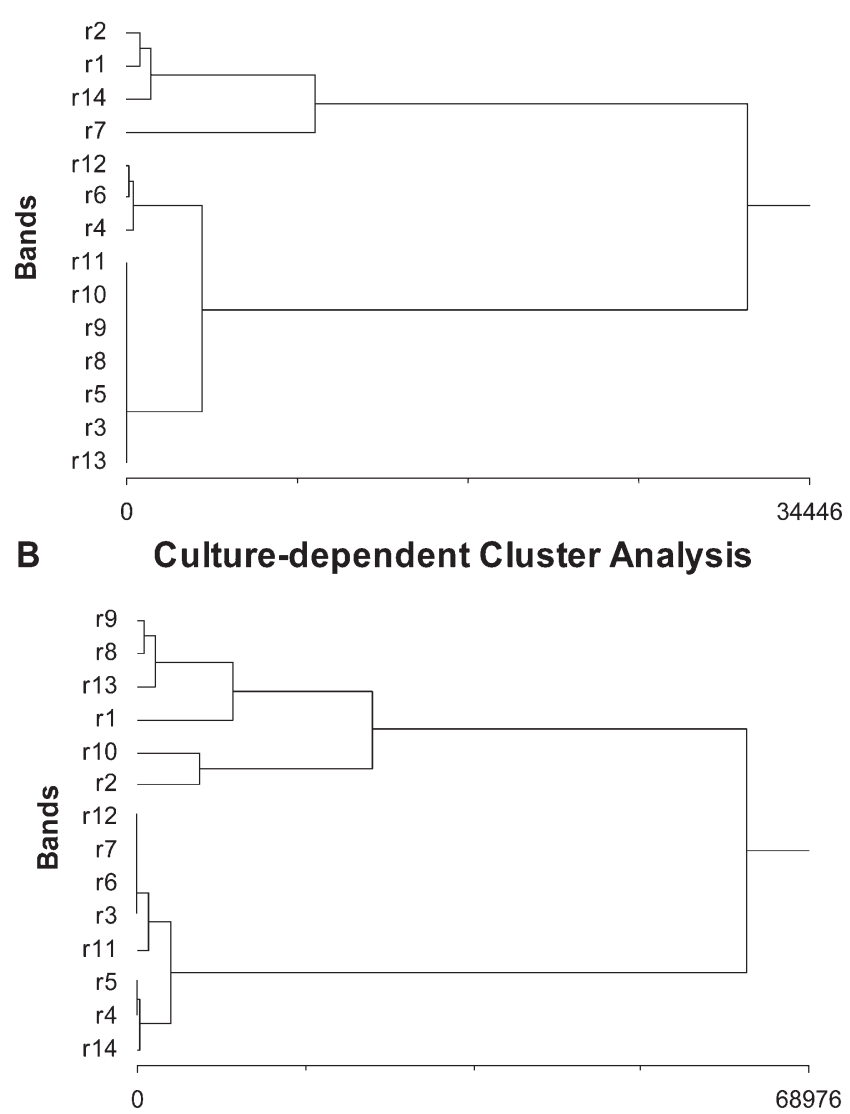

Figure 3. Cluster analysis of DGGE banding patterns from oysters collected in Spinney Creek. $r$ Values correspond to Figure 1B.

bacteria were more abundant with the increase in temperature. This increase in abundance would translate into successful PCR amplification and DGGE gel visualization, leading to more uniform community profiles. The observed increase in bands may also correspond with spring bloom increases in primary production and bacterial biomass.

Oyster-associated DGGE profiles produced greater numbers of bands than the seawater profiles, and the Sorensen similarity coefficient was low $\left(\mathrm{C}_{\mathrm{s}}<0.50\right)$, both indicating that the abundance of dominant ribotypes was greater in the oyster than in the seawater. Similar studies have resulted in the same conclusions. For example, a comparative study on the composition and seasonal fluctuations of main bacterial groups isolated from Mediterranean oysters and their growing seawater indicated a profound difference in both the dominant species and diversity of bacteria (Pujalte et al. 1999). Seawater samples had lower relative diversity and did not show an apparent seasonality in the distribution of species. Several additional studies have concluded that bivalve samples yield higher numbers and higher diversity of heterotrophic bacteria than seawater samples (Lovelace et al. 1968, Prieur et al. 1990, Pujalte et al. 1999). However, some similarities were observed between bacterial communities in the oyster and in the seawater. Although marine bacteria are usually present in low abundance in the low-nutrient concentrations found in the oceans (Kisand \& Wikner 2003), bacteria can elicit strategies that improve their likelihood of survival and opportunities to increase in abundance. For example, marine bacteria
A Culture-independent Cluster Analysis
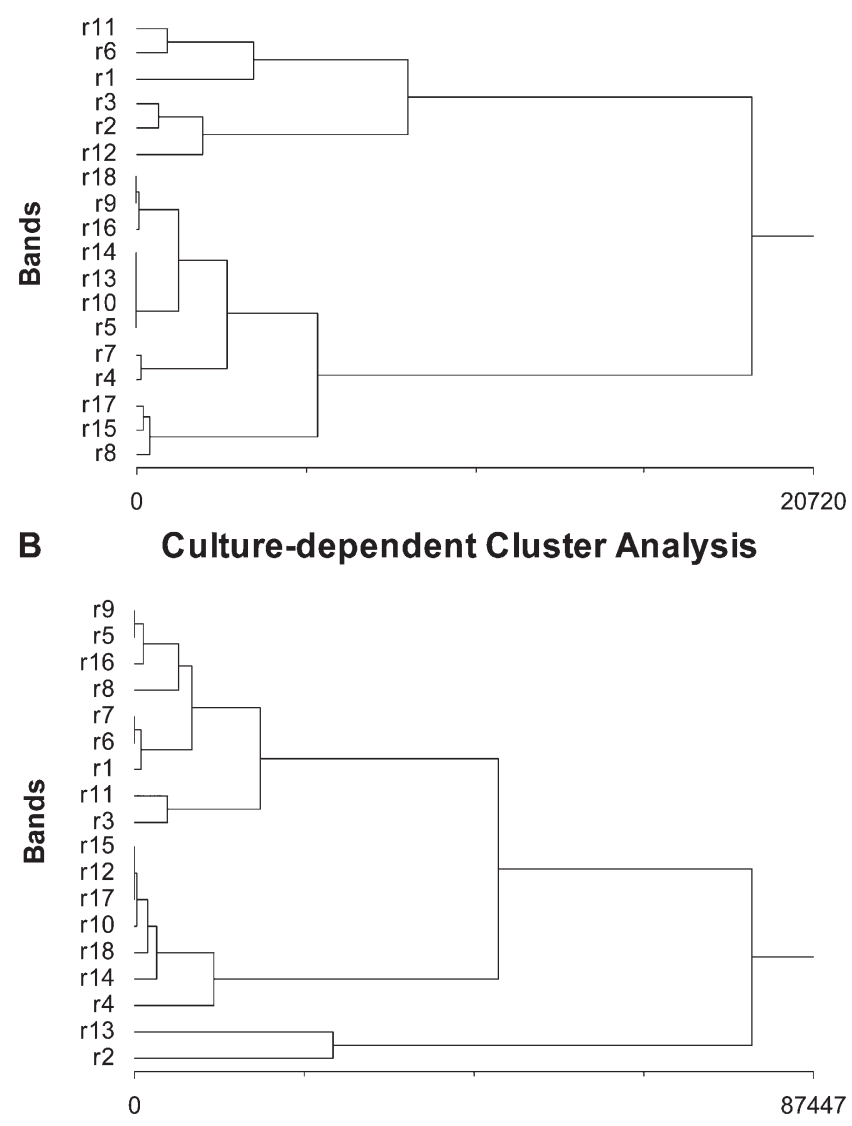

Figure 4. Cluster analysis of DGGE banding patterns from oysters collected in Bay Falls. r Values correspond to Figure 2B.

will attach to detritus particles and grow well under localized conditions that are relatively nutrient rich (Atlas \& Bartha 1993). The biofilms associated with oyster reefs are an example of a localized nutrient-rich habitat. Pronounced differences between the bacterial communities associated with oyster reef and nonreef habitats have been documented. Oyster reef biofilm communities have been observed to possess greater species richness and evenness than estimates from muddy sand bottoms (Nocker et al. 2004). These high-density microniches certainly expose filter feeding bivalves, such as the oyster, to greater concentrations of a variety of micro-organisms that may not otherwise be encountered in seawater.

Several biases have been associated with the use of DGGE in the analysis of bacterial communities. However, the introduced biases can be assumed to affect samples equally, if the samples have a common source and are similarly treated (Ramirez-Saad et al. 2003). For this experiment, all oysters were sampled from the same harvest area at the same time and treated similarly. Given that these biases have been shown to correspond positively with relative abundance of the observed species from a sample (Rohwer et al. 2001, Boon et al. 2002), it was assumed that the generated profiles represented the dominant ribotypes associated with the oyster for a specific harvest area. In DGGE, the number of different bands or peaks on the densitometric curve serve as a proxy for diversity, because the different ribosome types or ribotypes are considered unique to a group 
of organisms (Crosby \& Criddle 2003). However, it has been noted that a single band may not always represent a single bacterial strain or ribotype (Sekiguchi et al. 2001). Two major sources of error that have been identified for DGGE are heterologous rRNA operons (McCartney 2002) from the same organism and poor detection sensitivity of rare organisms. It has been estimated that DGGE profiles may represent as low as $90 \%$ of the bacterial community of a sample (Zoetendal et al. 1998). Crosby and Criddle (2003) demonstrated that the number of rRNA operons has an effect on community analysis techniques based on 16S rRNA genes. In this case, multiple bands may be detected for a single ribotype or organism.

In summary, the image of the oyster bacterial community provided by DGGE most likely relates more to population structure - that is, to the relative abundance of the main bacterial populations - than to its total richness. In addition, by combining culture-dependent and -independent methodologies, a more complete picture of the diversity of marine bacterial communities can be predicted (Ellis et al. 2003; Kisand \& Wikner, 2003).

\section{LITERATURE CITED}

Abrams, E. S. \& V. P. Stanton. 1992. Use of denaturing gradient gel electrophoresis to study conformational transitions in nucleic acids. Methods Enzymol. 212:71-104.

Amann, R. I., W. Ludwig \& K. H. Schleifer. 1995. Phylogenetic identification and in situ detection of individual microbial cells without cultivation. Microbiol. Rev. 59:143-169.

Atlas, R. M. \& R. Bartha. (1993) Microbial ecology: fundamentals and applications, 3rd ed. Redwood City, CA: Benjamin/Cummings Publishing.

Bernard, L., H. Schafer, F. Joux, C. Courties, G. Muyzer \& P. Lebaron. 2000. Genetic diversity of total, active and culturable marine bacteria in coastal seawater. Aquat. Microb. Ecol. 23:1-11.

Boon, N., W. De Windt, W. Verstraete \& E.M. Top. 2002. Evaluation of nested PCR-DGGE (denaturing gradient gel electrophoresis) with group-specific 16S rRNA primers for the analysis of bacterial communities from different wastewater treatment plants. FEMS Microbiol. Ecol. 39:101-112.

Brady, Y. J., C. R. Vines \& M. A. Delaney. (1998) Microbial flora of offshore relayed oysters, Crassostrea virginica, in Mobile Bay, Alabama. In: Aquaculture '98 Book of Abstracts, February 15-19, 1998, Las Vegas, Nevada. p. 63.

Brinkhoff, T. \& G. Muyzer. 1997. Increased species diversity and extended habitat range of sulfur-oxidizing Thiomicrospira spp. Appl. Environ. Microbiol. 63:3789-3796.

Burkhardt, W., III \& K. R. Calci. 2000. Selective accumulation may account for shellfish-associated viral illness. Appl. Environ. Microbiol. 66:1375-1378.

Cariello, N. F., J. A. Swenberg \& T. R. Skopek. 1991. Fidelity of Thermococcus litoralis DNA polymerase (Vent super ${ }^{\mathrm{TM}}$ ) in PCR determined by denaturing gradient gel electrophoresis. Nucl. Acids Res. 19:4193-4198.

Cottrell, M. T. \& D. L. Kirchman. 2000. Community composition of marine bacterioplankton determined by $16 \mathrm{~S}$ rRNA gene clone libraries and fluorescence in situ hybridization. Appl. Environ. Microbiol. 66:5116-5122.

Crosby, L. D. \& C. S. Criddle. 2003. Understanding bias in microbial community analysis techniques due to $r r n$ operon copy number heterogeneity. BioTechnology 34:2-9.

Dilly, O., J. Bloem, A. Vos \& J. C. Munch. 2004. Bacterial diversity in agricultural soils during litter decomposition. Appl. Environ. Microbiol. 70:468-474.

Don, R. H., P. T. Cox, B. J. Wainwright, K. Baker \& J. S. Mattick. 1991. "Touchdown" PCR to circumvent spurious priming during gene amplification. Nucl. Acids Res. 19:4008.

Duarte, G. F., A. S. Rosado, L. Seldin, A. C. Keijzer-Wolters \& J. Dirk van Elsas. 1998. Extraction of ribosomal RNA and genomic DNA from soil for studying the diversity of the indigenous bacterial community. J. Microbiol. Methods 32:21-29.

Ellis, R. J., P. Morgan, A. J. Weightman \& J. C. Fry. 2003. Cultivationdependent and -independent approaches for determining bacterial diversity in heavy-metal-contaminated soil. Appl. Environ. Microbiol. 69:3223-3230.
Ercolini, D., G. Moschetti, G. Blaiotta \& S. Coppola. 2001. The potential of a polyphasic PCR-DGGE approach in evaluating microbial diversity of natural whey cultures for water-buffalo mozzarella cheese production: bias of culture-dependent and culture-independent analyses. Syst. Appl. Microbiol. 24:610-617.

Fandino, L. B., L. Riemann, G. F. Steward, R. A. Long \& F. Azam. 2001. Variations in bacterial community structure during a dinoflagellate bloom analyzed by DGGE and $16 \mathrm{~S}$ rDNA sequencing. Aquat. Microb. Ecol. 23:119-130.

Friedrich, M., R. J. Grosser, E. A. Kern, W. P. Innskeep \& D. M. Ward. 2000. Effect of model sorptive phases on phenanthrene biodegradation: molecular analysis of enrichments and isolates suggests selection based on bioavailability. Appl. Environ. Microbiol. 66:2703-2710.

Furhman, J. A. \& L. Campbell. 1998. Microbial microdiversity. Nature 393:410-411.

Gelsomino, A., A. C. Keijzer-Wolters, G. Cacco \& J. Dirk van Elsas. 1999. Assessment of bacterial community structure in soil by polymerase chain reaction and denaturing gradient gel electrophoresis. J. Microbiol. Methods 38:1-15.

Head, I. M., J. R. Saunders \& R. W. Pickup. 1998. Microbial evolution, diversity and ecology: a decade of ribosomal RNA analysis of uncultivated microorganisms. Microb. Ecol. 35:1-21.

Henckel, T., M. Friedrich \& R. Conrad. 1999. Molecular analyses of the methane-oxidizing microbial community in rice field soil by targeting the genes of the 16S rRNA, particulate methane monooxygenase, and methanol dehydrogenase. Appl. Environ. Microbiol. 65:1980-1990.

Kawai, M., E. Matusutera, H. Kanda, N. Yamaguchi, K. Tani \& M. Nasu. 2002. 16S ribosomal DNA-based analysis of bacterial diversity in purified water used in pharmaceutical manufacturing processes by PCR and denaturing gradient gel electrophoresis. Appl. Environ. Microbiol. 68:699-704.

Keohavong, P., L. Ling, C. Dias \& W. G. Thilly. 1993. Predominant mutations induced by the Thermococcus litoralis vent DNA polymerase during DNA amplification in vitro. PCR Methods Appl. 2:288-292.

Kirk, J. L., L. A. Beaudette, M. Hart, P. Moutoglis, J. N. Klironomos, H. Lee \& J. T. Trevors. 2004. Methods of studying soil microbial diversity. J. Microbiol. Methods 58:169-188.

Kisand, V. \& J. Wikner. 2003. Combining culture-dependent and -independent methodologies for estimation of richness of estuarine bacterioplankton consuming riverine dissolved organic matter. Appl. Environ. Microbiol. 69:3607-3616.

Kowalchuk, G. A., J. R. Stephen, W. De-Boer, J. I. Prosser, T. M. Embley \& J. W. Woldendorp. 1997. Analysis of ammonia-oxidizing bacteria of the beta subdivision of the class Proteobacteria in coastal sand dunes by denaturing gradient gel electrophoresis and sequencing of PCR-amplified $16 \mathrm{~S}$ ribosomal DNA fragments. Appl. Environ. Microbiol. 63:1489-1497.

Lovelace, T. E., H. Tubiash \& R. R. Colwell. 1968. Quantitative and qualitative commensal bacterial flora of Crassostrea virginica in Chesapeake Bay. Proc. Natl. Shellfish. Assoc. 58:82-87. 
McCaig, A. E., L. A. Glover \& J. I. Prosser. 2001. Numerical analysis of grassland bacterial community structure under different land management regimens by using $16 \mathrm{~S}$ ribosomal DNA sequence data and denaturing gradient gel electrophoresis banding patters. Appl. Environ. Microbiol. 67:4554-4559.

McCartney, A. L. 2002. Application of molecular biological methods for studying probiotics and the gut flora. Br. J. Nutr. 88:S29-S37.

Metcalf, T. G., B. Mullin, D. Eckerson, E. Moulton \& E. P. Larkin. 1979. Bioaccumulation and depuration of enteroviruses by the softshelled clam, Mya arenaria. Appl. Environ. Microbiol. 38:275-282.

Miambi, E., J. P. Guyot \& F. Ampe. 2003. Identification, isolation and quantification of representative bacteria from fermented cassava dough using an integrated approach of culture-dependent and culture-independent methods. Int. J. Food Microbiol. 82:1111-1120.

Miller, K. M., T. J. Ming, A. D. Schulze \& R. E. Withler. 1999. Denaturing gradient gel electrophoresis (DGGE): a rapid and sensitive technique to screen nucleotide sequence variation in populations. BioTechnology 27:1016-1030.

Muyzer, G., E. C. De Waal \& A. G. Uitterlinden. 1993. Profiling of complex microbial populations by denaturing gradient gel electrophoresis analysis of polymerase chain reaction-amplified genes coding for 16S rRNA. Appl. Environ. Microbiol. 59:695-700.

Nakatsu, C. H., V. Torsvik \& L. Ovreas. 2000. Soil community analysis using DGGE of $16 \mathrm{~S}$ rDNA polymerase chain reaction products. $S$. Sc. Soc. Am. J. 64:1382-1388.

Nocker, A., J. E. Lepo \& R. A. Snyder. 2004. Influence of an oyster reef on development of the microbial heterotrophic community of an estuarine biofilm. Appl. Environ. Microbiol. 70:6834-6845.

Norman, J. A., C. Moritz \& C. J. Limpus. 1994. Mitochondrial DNA control region polymorphisms: genetic markers for ecological studies of marine turtles. Mol. Ecol. 3:363-373.

Olafsen, J. A., H. V. Mikkelsen, H. M. Giaever \& G. H. Hansen. 1993. Indigenous bacteria in hemolymph and tissues of marine bivalves at low temperatures. Appl. Environ. Microbiol. 59:1848-1854.

Ovreas, L., L. Forney, F. L. Daae \& V. Torsvik. 1997. Distribution of bacterioplankton in meromictic Lake Saelenvannet, as determined by denaturing gradient gel electrophoresis of PCR-amplified gene fragments coding for 16S rRNA. Appl. Environ. Microbiol. 63:3367-3373.

Prieur, D., G. Mvel, J. L. Nicolas, A. Plusquellec \& M. Vigneulle. 1990. Interactions between bivalve mollusks and bacteria in the marine environment. Oceanogr. Mar. Biol. Annu. Rev. 28:277-352.

Pujalte, M. J., M. Ortigosa, M. C. Macian \& E. Garay. 1999. Aerobic and facultative anaerobic heterotrophic bacteria associated to Mediterranean oysters and seawater. Intl. Microbiol. 2:259-266.

Ramirez-Saad, H. C., A. Sessitsch \& A. D. L. Akkermans. 2003. Molecular diversity in the bacterial community and the fluorescent pseudomonads group in natural and chlorobenzoate-stressed peatforest soil. Microbiol. Res. 158:47-54.

Rantsiou, K., R. Urso, L. Iacumin, C. Cantoni, P. Cattaneo, G. Comi \& L. Cocolin. 2005. Culture-dependent and -independent methods to investigate the microbial ecology of Italian fermented sausages. Appl. Environ. Microbiol. 71:1977-1986.

Riemann, L., G. F. Steward, L. B. Fandino, L. Campbell, M. R. Landry \& F. Azam. 1999. Bacterial community composition during two consecutive NE monsoon periods in the Arabian Sea studied by denaturing gradient gel electrophoresis (DGGE) of rRNA genes. Deep-Sea Res. II 46:1791-1811.

Rippey, S. R., W. N. Adams \& W. D. Watkins. 1994. Infectious diseases associated with molluscan shellfish consumption. Clin. Microbiol. Rev. 7:419-425.

Rohwer, F., M. Breitbart \& J. Jara. 2001. Diversity of bacteria associated with the Caribbean coral Montastraea franksi. Coral Reefs 20:85-91.
Santegoeds, C. M., S. C. Nold \& D. M. Ward. 1996. Denaturing gradient gel electrophoresis used to monitor the enrichment culture of aerobic chemoorganotrophic bacteria from a hot spring cyanobacterial mat. Appl. Environ. Microbiol. 62:3922-3928.

Schauer, M., V. Balague, C. Pedros-Alio \& R. Massana. 2003. Seasonal changes in the taxonomic composition of bacterioplankton in a coastal oligotrophic system. Aquat. Microb. Ecol. 31:163-174.

Seibold, A., A. Wichels \& C. Schutt. 2001. Diversity of endocytic bacteria in the dinoflagellate Noctiluca scintillans. Aquat. Microb. Ecol. 25:229-235.

Sekiguchi, H., N. Tomioka, T. Nakahara \& H. Uchiyama. 2001. A single band does not always represent single bacterial strains in denaturing gradient gel electrophoresis analysis. Biotechnol. Lett. 23:1205-1208.

Shannon, C. E. 1948. A mathematical theory of communication. Bell Syst. Tech. J. 27:379-423.

Simpson, J. M., V. J. McCracken, H. R. Gaskins \& R. Mackie. 2000. Denaturing gradient gel electrophoresis analysis of $16 \mathrm{~S}$ ribosomal DNA amplicons to monitor changes in fecal bacterial populations of weaning pigs after introduction of Lactobacillus reuteri strain MM53. Appl. Environ. Microbiol. 66:47054714.

Simpson, J. M., V. J. McCracken, B. A. White, H. R. Gaskins \& R. Mackie. 1999. Application of denaturant gradient gel electrophoresis for the analysis of the porcine gastrointestinal microbiota. $J$. Microbiol. Methods 36:167-179.

Smit, E., P. Leeflang, S. Gommans, J. van den Broek, S. van Mil \& K. Wernars. 2001. Diversity and seasonal fluctuations of the dominant members of the bacterial soil community in a wheat field as determined by cultivation and molecular methods. Appl. Environ. Microbiol. 67:2284-2291.

Staroscik, A. M. \& D. C. Smith. 2004. Seasonal patterns in bacterioplankton abundance and production in Narragansett Bay, Rhode Island, USA. Aquat. Microb. Ecol. 35:275-282.

Temmerman, R., L. Masco, T. Vanhoutte, G. Huys \& J. Swings. 2003. Development and validation of a nested-PCR-denaturing gradient gel electrophoresis method for taxonomic characterization of Bifidobacterial communities. Appl. Environ. Microbiol. 69:6380 6385.

U.S. FDA Bacteriological Analytical Manual, 8th Edition, Revision A, 1998. Prepared and edited by: Robert I. Merker, Office of Special Research Skills, CFSAN, FDA.

Vetriani, C., H. W. Jannasch, B. J. MacGregor, D. A. Stahl \& A.L. Reysenbach. 1999. Population structure and phylogenetic characterization of marine benthic Archaea in deep-sea sediments. Appl. Environ. Microbiol. 65:4375-4384.

Wakefield, J. R. \& P. M. Gaffney. 2002. DGGE reveals additional population structure in Eastern Oyster (Crassostrea virginica) populations. J. Shellfish Res. 15:513.

Ward, J. H. 1963. Hierarchical grouping to optimize an objective function. J. Am. Stat. Assoc. 58:236.

Wawer, C. \& G. Muyzer. 1995. Genetic diversity of Desulfovibrio spp. in environmental samples analyzed by denaturing gradient gel electrophoresis of $[\mathrm{NiFe}]$ hydrogenase gene fragments. Appl. Environ. Microbiol. 61:2203-2210.

Zobell, C. E. 1941. Studies on marine bacteria. I. The cultural requirements of heterotrophic aerobes. J. Mar. Res. 4:42-75.

Zoetendal, E. G., A. Akkermans \& W. M. De Vos. 1998. Temperature gradient gel electrophoresis analysis of 16S rRNA from human fecal samples reveals stable and host-specific communities of active bacteria. Appl. Environ. Microbiol. 64:38543859 . 